\title{
In the Quest for Meaning
}

\section{The Constant Fire}

Beyond the Science vs. Religion Debate ADAM FRANK

"In the midst of increasing polarization in discussions about science and religion, as well as political aspects of both, it is a relief to encounter a voice of reason that at the same time articulates a sensitivity and sensibility sorely lacking in so many discussions nowadays." - -Piet Hut, Institute for Advanced Study, Princeton \$24.95 cloth
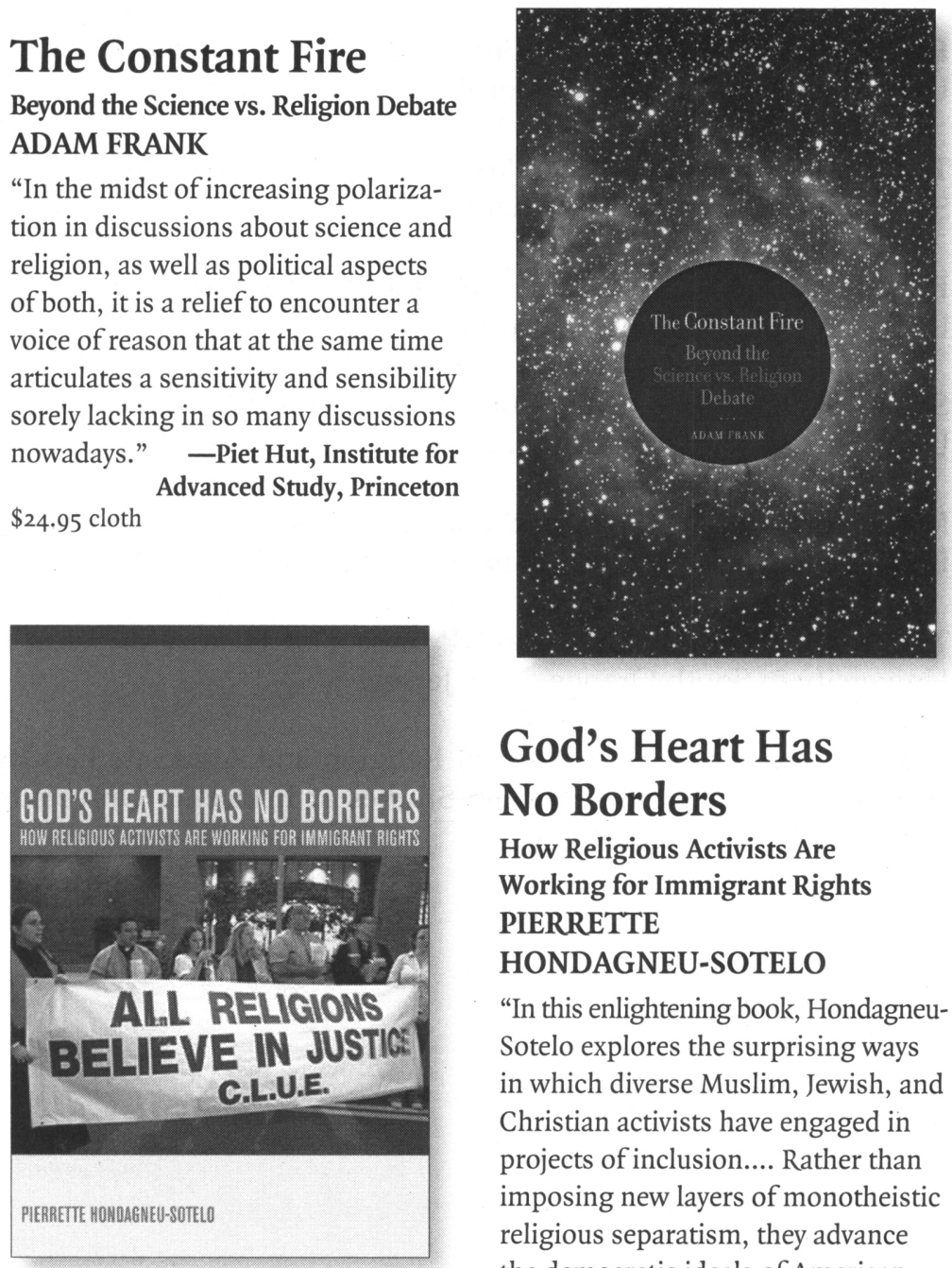

\section{God's Heart Has} No Borders

How Religious Activists Are

Working for Immigrant Rights

PIERRETTE

\section{HONDAGNEU-SOTELO}

"In this enlightening book, HondagneuSotelo explores the surprising ways in which diverse Muslim, Jewish, and Christian activists have engaged in projects of inclusion.... Rather than imposing new layers of monotheistic religious separatism, they advance the democratic ideals of American pluralism." -Rubén G. Rumbaut, coauthor of Immigrant America and Legacies \$55.00 cloth, \$21.95 paper

At bookstores or order (80o) 822-6657 • www.ucpress.edu 


\section{Them That Believe}

The Power and Meaning of the Christian Serpent-Handling Tradition RALPH W. HOOD, JR., and W. PAUL WILLIAMSON

"One of the most comprehensive and thoroughly researched reports on serpent handling Christians ever written. The use of multiple methodological lenses....adds a depth and richness not seen in other works."

-Stephen Parker, author of Led by the Spirit

$\$ 60.00$ cloth, $\$ 24.95$ paper

\section{Inventing America's "Worst" Family}

Eugenics, Islam, and the Fall and Rise of the Tribe of Ishmael NATHANIEL DEUTSCH

"Important, refreshing, and interesting. Perhaps the most fascinating aspect of this account is its placement at the center of a larger narrative about America's obsession with Orientalism."-Wendy Kline, author of Building a Better Race $\$ 60.00$ cloth, $\$ 24.95$ paper

\section{Unsettled Minds}

Psychology and the American Search for Spiritual Assurance, 1830-1940 CHRISTOPHER G. WHITE

"An important contribution to the growing literature on the history of religious experience and of the distinctive dynamics of Christian interiority in the modern U.S."

-Robert Orsi, Northwestern University
NEW IN PAPERBACK

The Search for Meaning

A Short History DENNIS FORD

"Touching on a wide range of philosophical, religious, and scientific approaches to the search for meaning throughout history, Ford sheds light on our relationship to these questions today, illuminating many of our most unconscious beliefs and unexamined assumptions in the process." -What Is Enlightenment \$16.95 paper

\section{Christmas}

\section{A Candid History}

BRUCE DAVID FORBES

"Valuable for its well-proven insistence that Christmas has always been as much a social and commercial festival as a religious one, debunking naïve assumptions that it used to be a purely spiritual holiday in a bygone halcyon age."-Publishers Weekly \$12.95 paper

\section{Godly Republic}

A Centrist Blueprint for America's Faith-Based Future JOHN J. DIIULIO, JR.

"An enlightening book."

-Christian Century

$\$ 16.95$ paper

At bookstores or order (80o) 822-6657 • www.ucpress.edu 


\section{Jewish Social Studies}

History, Culture, and Society

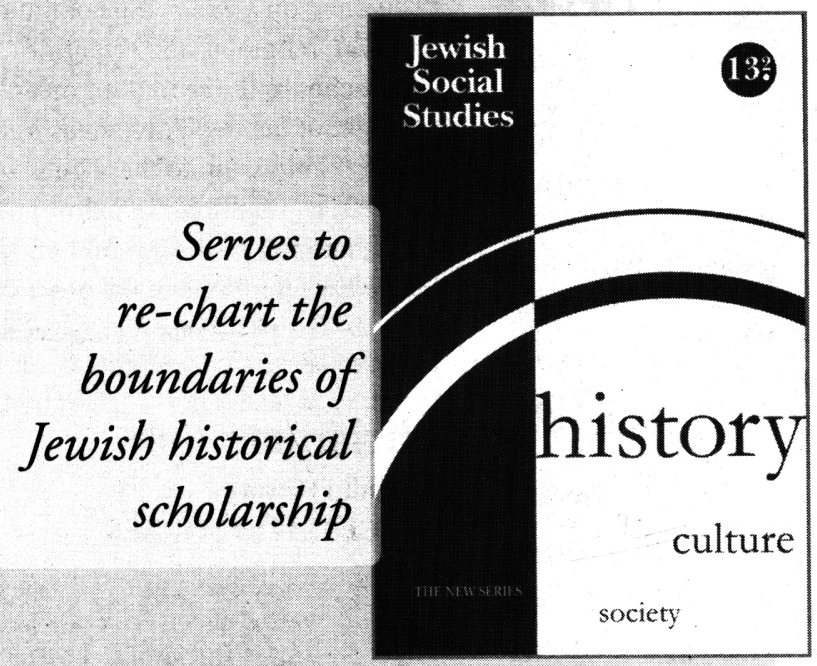

Edited by Derek Penslar, Aron Rodrigue, and Steven J. Zipperstein

$p-$ ISSN $0021-6704$
e- ISSN $1527-2028$

Jewish Social Studies plays an important role in advancing the understanding of Jewish life and the Jewish past. Key themes are issues of identity and peoplehood, the vistas opened by the integration of gender as a primary category in the study of history, and the multiplicities inherent in the evolution of Jewish societies and cultures around the world and over time.

Institutions:

print $\$ 97.00$

electronic $\$ 87.30$

print \& electronic $\$ 135.80$
Individuals:

print $\$ 37.50$

electronic $\$ 35.55$

print \& electronic $\$ 43.45$

Now available

on...

inscribe 


\begin{tabular}{|c|c|c|}
\hline \multicolumn{3}{|c|}{ New from Stanford } \\
\hline $\begin{array}{l}\text { IVIC LFE } \\
\text { ERICA } \\
\text { IGIO }\end{array}$ & $\begin{array}{l}\text { The Civic Life of } \\
\text { American Religion } \\
\text { Edited by } \\
\text { PAUL LICHTERMAN and } \\
\text { C. BRADY POTTS } \\
\text { "A lot of books lately extol the } \\
\text { virtues of religion for American } \\
\text { civil society. In contrast, this work } \\
\text { offers interpretive essays-backed } \\
\text { by systematic research—-that pro- } \\
\text { vide a balanced assessment of both } \\
\text { the benefits and drawbacks of reli- } \\
\text { gion in civic life, and point out } \\
\text { directions for new theoretical and } \\
\text { empirical work." } \\
\quad \text {-Rhys Williams, } \\
\text { University of Cincinnat } \\
\text { \$19.95 paper \$50.00 cloth }\end{array}$ & $\begin{array}{l}\text { Bleached Faith } \\
\text { The Tragic Cost When } \\
\text { Religion Is Forced into the } \\
\text { Public Square } \\
\text { STEVEN G OLD BERG } \\
\text { Bleached Faith argues that the } \\
\text { gravest threat to real faith in mod- } \\
\text { ern America comes from those who } \\
\text { would water down religion in } \\
\text { order to win the dubious honor of } \\
\text { forcing it into public buildings and } \\
\text { classrooms. } \\
\$ 24.95 \text { cloth }\end{array}$ \\
\hline & & .621 .2736 www.sup.org \\
\hline
\end{tabular}




\section{Indiana University Press/Journals}

\section{Journal of Feminist Studies in Religion}

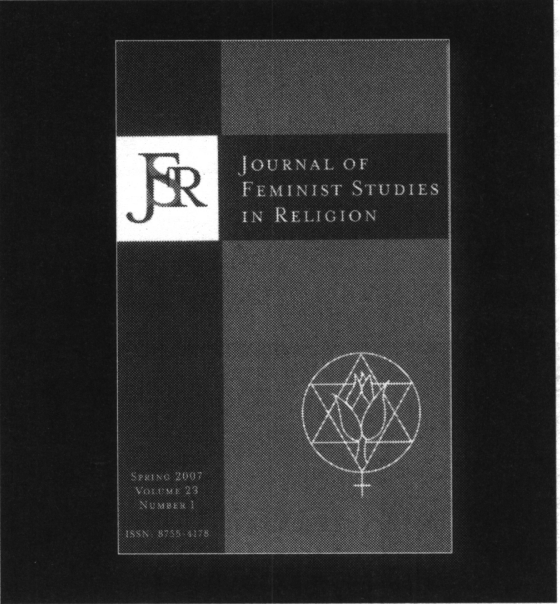

Edited by Elisabeth Schüssler Fiorenza, Melanie Johnson-DeBaufre, and Stephanie Mitchem The Journal of Feminist Studies in Religion, the oldest interdisciplinary, inter-religious feminist academic journal in religious studies, is a channel for the publication of feminist scholarship in religion and a forum for discussion and dialogue among women and men of differing feminist perspectives. Its editors are committed to rigorous thinking and analysis in the service of the transformation of religious studies as a discipline and the feminist transformation of religious and cultural institutions. 


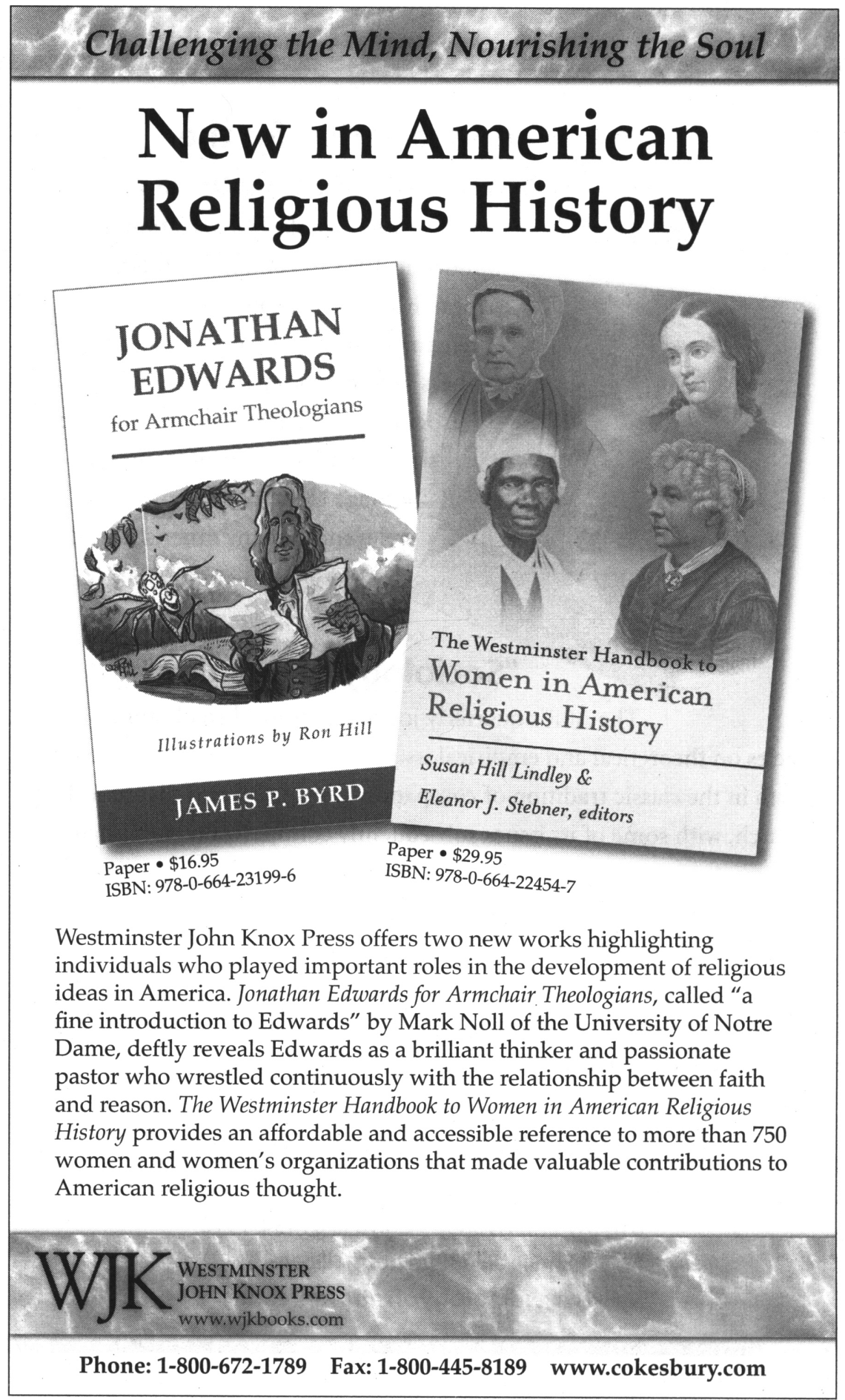




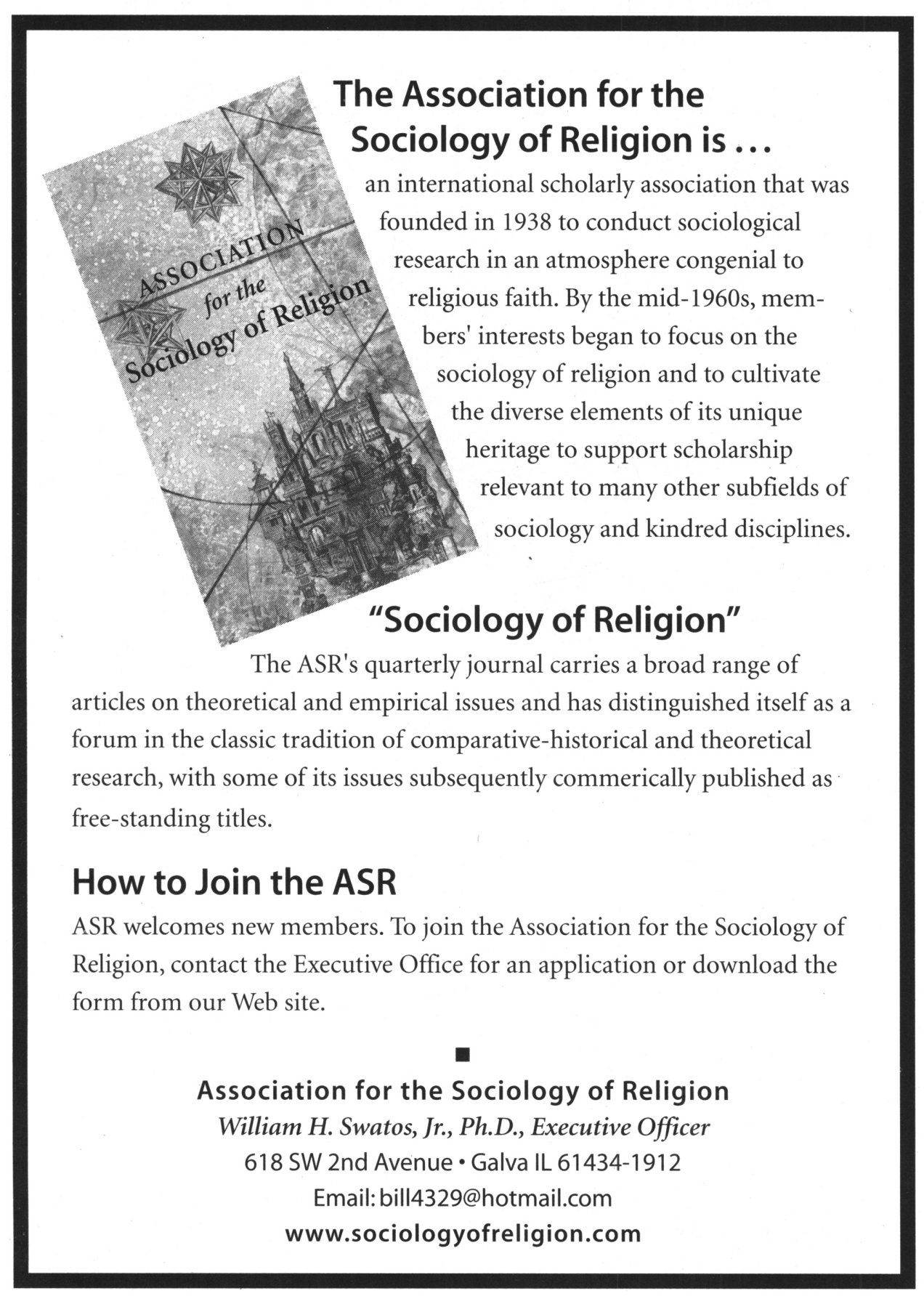


